\title{
REVIEW
}

Open Access

\section{The challenge of combining variable retention and prescribed burning in Finland}

\author{
Henrik Lindberg ${ }^{*^{*}}$, Pekka Punttila ${ }^{2}$ and Ilkka Vanha-Majamaa ${ }^{3}$
}

\begin{abstract}
Historically, wildfires have played an important role in forest dynamics in Fennoscandia. In Finland, the annually burned area has diminished in recent decades. This has led to a decline of fire-adapted habitat types and species, many of which have become red-listed. In Fennoscandia, there is a long tradition of silvicultural burnings to enhance tree regeneration. Recently, prescribed burnings have been modified for biodiversity goals following the recommendations that have emerged from ecological research. Prominent biodiversity gains can be obtained by combining sufficient retention levels with burnings. Consequently, burning and retention have been recommended by recent national red-list assessments, strategies, and forest-management guidelines, and they have been adopted in forest-certification standards in Finland. Contrary to these recommendations, the opposite development has taken place: (1) the ecological efficiency of the criterion concerning prescribed burning in the PEFC forestcertification standard has been impaired, (2) state funding to encourage private forest owners to apply prescribed burning was reduced significantly, and (3) prescribed burnings have been abandoned altogether in commercial state-owned forests. Traditional burnings with variable retention have also been partially replaced with burning of small retention-tree groups. This new method is less risky and cheaper, but its ecological benefits are questionable because small-sized fires produce much smaller areas of burned forest soil with less fire-affected wood than traditional silvicultural burnings. Generally, the widely accepted goal to increase burnings with retention appears difficult to achieve and would require stronger political will and economic support from the government. We identified several actions that could improve the weakened situation of fire-dependent biodiversity and recommend the following: (1) setting a clear goal and ensuring sufficient funding for the burnings—including restoration burnings in conservation areas - and targeting these to specific fire-continuum areas with sufficient retention to ensure the continuity of fire-affected habitats at landscape level; (2) renewing the current subsidizing policies to encourage private landowners to perform prescribed burnings in regeneration areas after final fellings, and to safeguard accidental forest-fire areas as set-asides; (3) renewing the current prescribed-burning criterion of the Finnish PEFC forest-certification standard with more ambitious ecological goals; and (4) re-introducing prescribed burnings in commercial state forests where management targets are under political steering.
\end{abstract}

Keywords: Biodiversity, Conservation areas, Fire-dependent species, Forest certification, Red-listed species, Restoration burnings

\footnotetext{
*Correspondence: henrik.lindberg@hamk.fi

${ }^{1}$ Häme University of Applied Sciences, Visamäentie 35 A Box 230, Fl-13101

Hämeenlinna, Finland

Full list of author information is available at the end of the article
} 


\section{Background}

Forest fires are generally regarded in public as detrimental and a threat to the environment worldwide in many ecosystems, including boreal ecosystems, where millions of hectares may burn annually (Robinne et al. 2018). However, fire also has an important role e.g. in maintaining fire adapted habitat types and safeguarding species requiring them. In Finland, the forest ecosystems nowadays are almost totally excluded from the effects of forest fires because of intensive forestry and dense forest-road network together with effective fire detection and suppression, which has resulted in a decline of firedependent biodiversity (Vanha-Majamaa et al. 2004).

Natural disturbances are largely responsible for the structural and functional diversity of boreal forest ecosystems, and boreal biota are adapted to the variability of disturbance dynamics (Esseen et al. 1997). Pristine forests in Fennoscandia are characterized by diverse and complex dynamics, which can be classified into four types (stand-replacing, cohort, patch, and gap dynamics), all occurring in both pine- and spruce-dominated forests yet with varying degrees of commonness (Kuuluvainen and Aakala 2011). In two of these forest-dynamics types, wildfire plays an important role: (1) stand-replacing disturbances leading to even-aged stand dynamics are mostly driven by high-severity forest fires, and (2) partial disturbances leading to cohort dynamics are mainly driven by surface fires and prevail in pine-dominated forests (Kuuluvainen and Aakala 2011). Thus, fire plays an important role in the ecology of boreal forests and the effects of fire largely depend on fire severity (Viro 1974, Lynham et al. 1998), which in turn depends on the site type. Also, the successional patterns of tree stands are affected by fire by enhancing regeneration of pioneer tree species, especially deciduous trees (Weber et al. 1995, Vanha-Majamaa et al. 1996, Lampainen et al. 2004, Lilja et al. 2005).

The size and severity of fires show a large range of variability leading to variability in stand- and landscapelevel forest structures (Johnson 1992). Thus, maintenance of this natural variability should be the goal in biodiversity-oriented forest management (Bergeron et al. 2002). However, current forest management tends to reduce this variability: for example, fully regulated, evenaged management truncates the natural forest age distribution and eliminates old-growth forest stages from the landscape (Bergeron et al. 2002). The development of strategic-level forest-management planning approaches and silvicultural techniques designed to maintain a spectrum of forest compositions and structures at different scales in the landscape is one way of maintaining this variability (Bergeron et al. 2002, Kuuluvainen 2009, 2016). Therefore, it has been suggested that the practice of variable retention should be based on natural disturbance regimes. These kinds of practices have been recommended in e.g. North America (Hunter 1993, Franklin et al. 1997, Armstrong 1999, Bergeron et al. 1999, Gauthier et al. 2009) and Fennoscandia (Angelstam 1998, Vanha-Majamaa and Jalonen 2001, Kuuluvainen 2009). Combining variable harvesting with prescribed burning will mimic natural disturbance dynamics much better than conventional clear felling (Vanha-Majamaa and Jalonen 2001). Even though prescribed burnings do not fully mimic wildfires, as they are intentionally set at a chosen time in selected locations and circumstances, they can create similar structural elements such as charred and decaying wood, and dead wood in general, that are important for biodiversity (Esseen et al. 1997, Granström 2001). However, the current true retention levels in Finland can be significantly lower than those suggested by research as we discuss below (see also Kuuluvainen et al. 2019). The overall assessment of research on variable retention forestry in Fennoscandia is described by Gustafsson et al. (2020). They also describe the main ongoing restoration experiments in Fennoscandia, including prescribed burning (Gustafsson et al. 2020). Koivula and Vanha-Majamaa (2020) describe in detail the ecological effects of variable retention forestry and prescribed burning on various species groups in Fennoscandia, showing the importance of fire for especially many red-listed species.

Annually burned area in forest fires has declined significantly during the last century in Finland. According to the forest fire statistics of Metsähallitus (Finnish Forest Service), the average burned area in State forests (covering at that time approximately $40 \%$ of Finland's forests) was 8915 ha per year during 1870-1899 and 5851 ha per year during 1900-1939, respectively (Lehmusluoto 1956). The average size of a single wildfire, 70 ha during 1871-1900, was halved compared to the average of 33 ha during 1901-1920 (Saari 1923).

A steep decrease in annually burned area in Finland happened during the 1950s and 1960s, when it was reduced to less than 1000 ha (Fig. 1). The average annual burned area was 5760 ha in the 1950s and only 936 ha in the 1970s (Aarne 1992). In recent decades, the annually burned area has mainly varied between 200 and 700 ha, occasionally exceeding 1000 ha (Peltola 2014). At the same time, the size of single wildfires has been reduced to an average of only 0.4 ha during the last two decades (Peltola 2014). Also, the sizes of large single wildfires have decreased. The last fire exceeding 10,000 ha was Tuntsa fire in northern Finland in the year 1960 when 20,000 ha was burned in Finland and 100,000 ha on the Soviet Union side of the border (Haataja 1998). The last wildfire exceeding 1000 ha occurred in the year 1970, and the last one with hundreds of hectares in the year 1997 (Fig. 1). Since then, single wildfires have been 


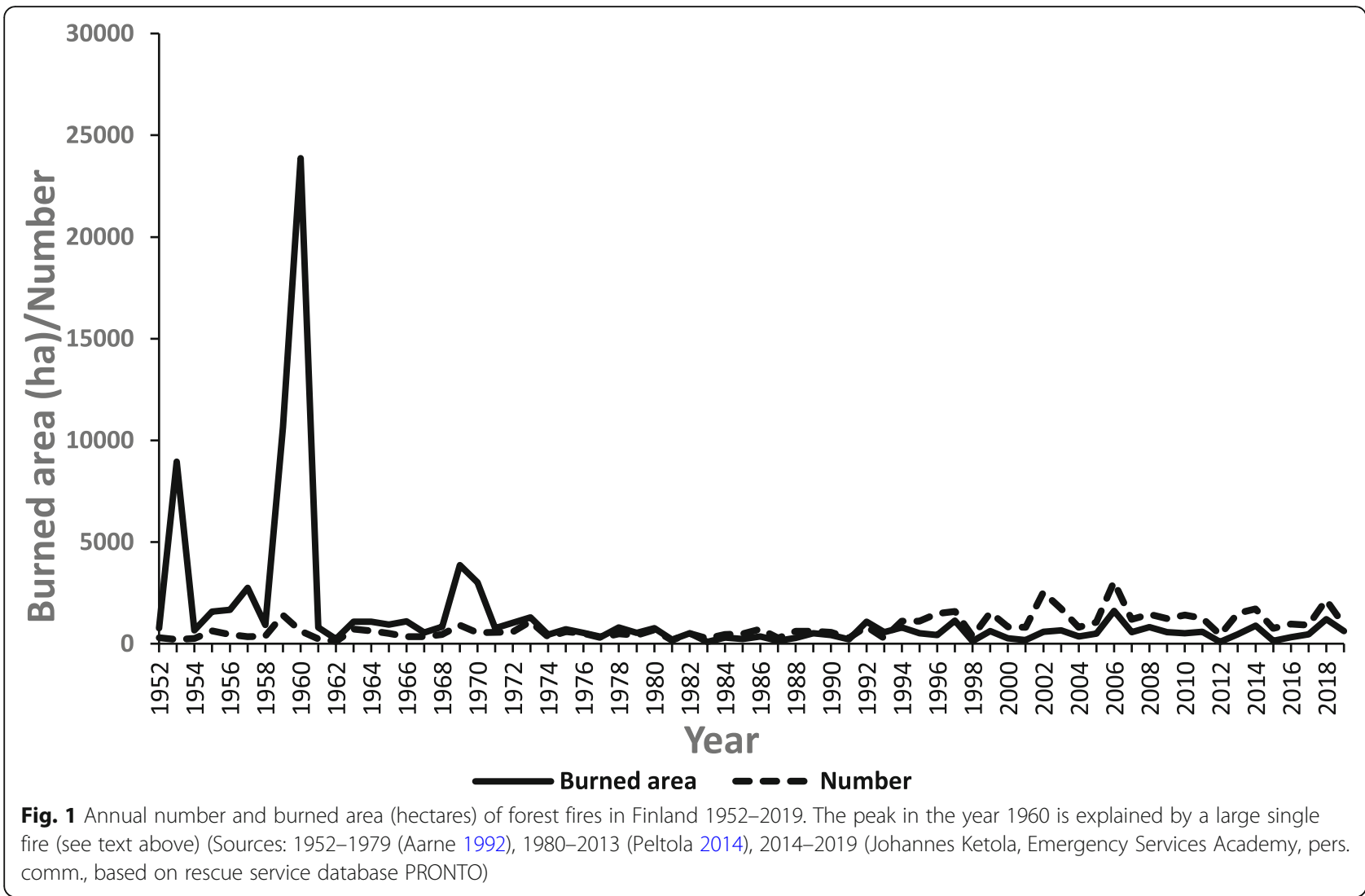

mostly under 100 ha, with a few between 100 and 200 ha. It is notable that, even in recent years, there has been no increase in annually burned area nor has there been an increase in large wildfires (Fig. 1), so Finland's fire regime differs significantly from that of neighboring Sweden, where annually burned areas in recent decades have been larger, and occasional wildfires covering hundreds of or even 1000-2000 ha have occurred randomly but frequently. Recently, there has been an escalating trend in wildfires in Sweden. In 2014, a mega-fire (over 10,000 ha, Stephens et al. 2014) occurred in Västmanland (Gustafsson et al. 2019), and, in 2018, a total area of 25,000 ha was burned with the largest single wildfire covering 9500 ha (Betänkande av 2018 års skogsbrandsutredning 2019). However, similar development is not apparent in Finland since these years do not stand out from the relatively normal low level of annually burned area in Finland (Fig. 1).

The decline of forest fires in Finland has caused concern about the negative biodiversity effects of the absence of fire. The pioneering biodiversity-oriented research experiments with fire were based on burnings with no cuttings or a significant amount of retention. The first biodiversity-oriented experimental fires were conducted in Patvinsuo National Park in eastern Finland in 1989 and in the Evo area in southern Finland in 1992.
In these burnings, polyporous fungi, for example, were monitored and the results showed the positive effects of burning on the occurrence and abundance of rare and threatened species (Penttilä and Kotiranta 1996, Penttilä et al. 2013). These pioneering case studies were followed by two large-scale replicated research experiments combining prescribed burnings with variable retention in both Scots pine (Pinus sylvestris L.)-dominated (Kouki 2019) and Norway spruce (Picea abies (L.) H. Karst.)-dominated (Vanha-Majamaa et al. 2007) stands in eastern and southern Finland, respectively, at the beginning of 2000s (Fig. 2). The results from these experiments and several other complementary studies have shown that burning is an effective nature-management tool in increasing the diversity and especially the abundance of rare and threatened species, particularly in polypores (Olsson and Jonsson 2010, Berglund et al. 2011, Penttilä et al. 2013, Suominen et al. 2015), beetles (Hyvärinen et al. 2005, 2006, 2009, Toivanen and Kotiaho 2007a, 2007b, Heikkala et al. 2016), and flat bugs (Heikkala et al. 2017). The recent results of Salo (2019) show that prescribed burnings with retention have positive effects on also mycorrhizal and saprotrophic macrofungi and thus can be recommended as an alternative to clear-cuttings. Although research has mainly concentrated on pyrophilous and saproxylic species, the burnings also seem to have generally favorable effects on other 


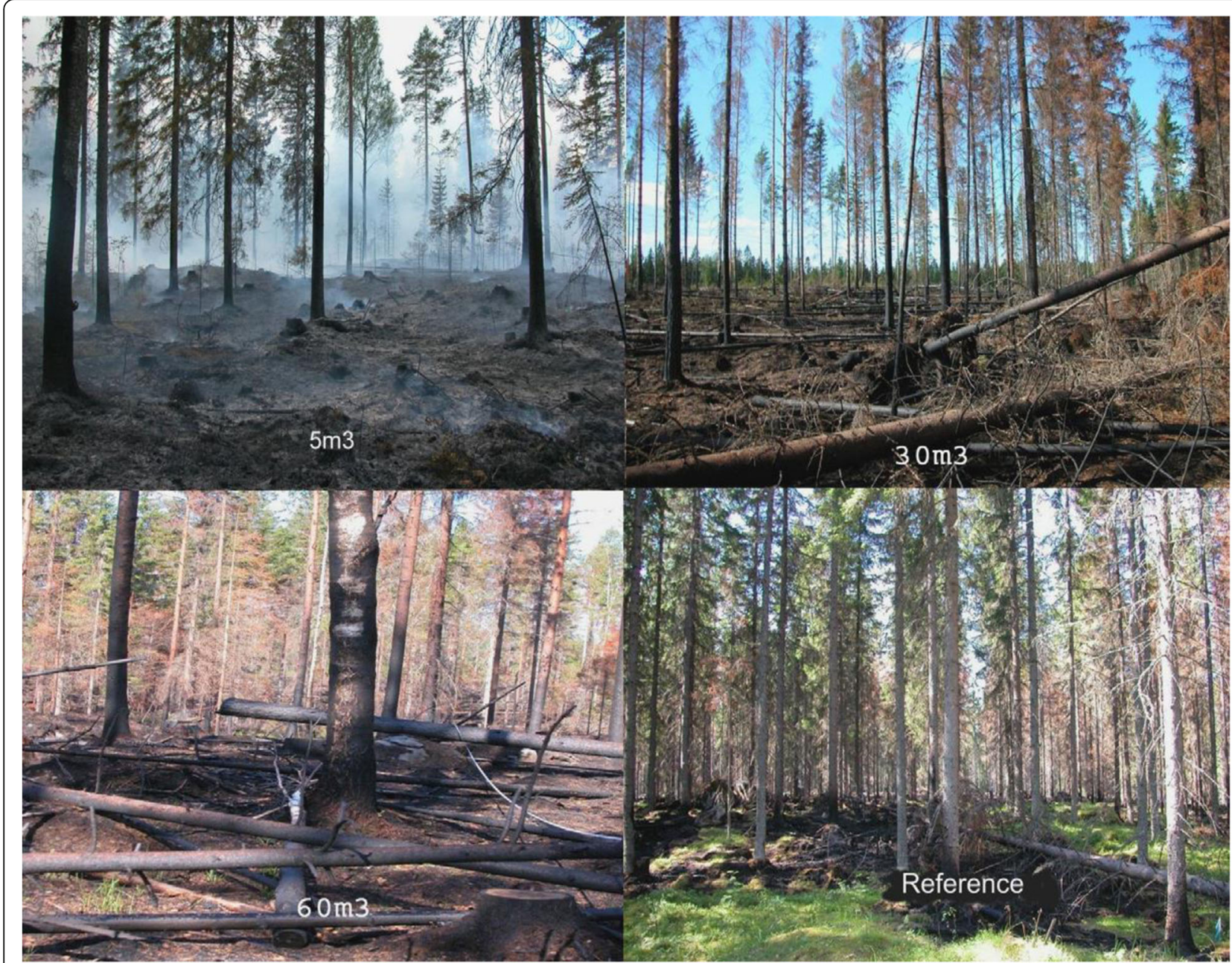

Fig. 2 Experimental burning treatments in Norway spruce-dominated stands with a standing retention of $50 \mathrm{~m}^{3} /$ ha and three different levels of down wood retention (5, 30, and $60 \mathrm{~m}^{3} / \mathrm{ha}$ ) and uncut reference in the Evo area, southern Finland, 2002. From Vanha-Majamaa et al. (2007), photos Erkki Oksanen/Natural Resources Institute Finland

species groups, yet the responses vary significantly (Eales et al. 2018). Recently, it has been shown that prescribed burnings are also beneficial to ecosystem services such as pollination and yields of edible forest berries (Rodríguez and Kouki 2015) and edible mushrooms (Salo 2019). On the other hand, burnings may also have negative effects on, e.g., air (Haikerwal et al. 2015) and water (Neary et al. 2005) quality hindering or limiting the use of burnings.

Red-list assessments show that the decrease in burned area in forest fires has led to the decline of numerous species (Hyvärinen et al. 2019) and even habitat types (Kontula and Raunio 2018) in Finland. According to the 2019 Red List of Finnish species, 3\% of threatened forest-dwelling species are considered fire-dependent (Hyvärinen et al. 2019). In addition, the reduction of burnt forest areas and other early stages of natural succession is one of the causes of the decline for 85 species out of 1587 threatened and near-threatened forest species (Hyvärinen et al. 2019). It is notable that barren xeric habitats, especially sun-exposed (sun-lit) pinedominated esker forests, have declined. The absence of fire affects the ecological characteristics and quality of these habitat types by transforming them gradually to more mesic and moist forest habitats due to the predominance of moss layer and accumulation of raw humus (From 2005, Tukia et al. 2015). Consequently, esker forests and nutrient-poor and xeric forests have been classified as threatened habitats in Finnish national red list assessments (Raunio et al. 2008, Kontula and Raunio 2018), and the red-listed species in these habitats make up 16\% of all threatened forest species (Hyvärinen et al. 2019).

For the abovementioned reasons, increasing prescribed burnings have been strongly recommended in practically all recent national nature-conservation assessments and guidelines in Finland (e.g., Raunio et al. 2008, Rassi et al. 
2010, Kotiaho et al. 2015, Kontula and Raunio 2018, Äijälä et al. 2019, Hyvärinen et al. 2019), and they have been included in all the updates of the national forest certification standards (PEFC and FSC) from the beginning of their development (Suomen metsäsertifiointijärjestelmä 1998, Metsäsertifioinnin standardityöryhmä 2003, The Board of the Finnish FSC Association 2005, PEFC Finland 2009, Finnish FSC Association 2010, PEFC Finland 2014). Finally, promoting nature management through prescribed burning was included in the current Finnish Government Programme as a measure to achieve the objective of halting the decline of biodiversity in Finland (Programme of Prime Minister Sanna Marin's Government 2019).

\section{Prescribed burning methods in Finland}

The scope of prescribed burnings in Finland has widened in recent years to include a diverse palette of burnings with different ecological targets and they can be divided into four groups:

- Silvicultural prescribed burnings of clear-cut areas

- Burnings of single retention-tree groups

- Impoverishment burnings or management burnings of sun-exposed and xeric habitats

- Restoration burnings

The traditional silvicultural prescribed burnings of clear-cut areas aim to improve regeneration conditions by improving nutrient cycling and creating an ashfertilization effect, decreasing the competition of understory vegetation, and improving general forest pathological hygiene (Viro 1969, Parviainen 1996). In such burnings, the aim is to burn slash and partly the moss and raw-humus layers (Viro 1969, Parviainen 1996). In many other parts of the world like southern Europe and North America, prescribed burnings mainly aim to reduce fuel load and fire risk, restore and maintain ecosystem types, and manage habitats for grazing and wildlife (Fernandes et al. 2013, Ryan et al. 2013). The practice and still ongoing tradition of silvicultural burnings as described above can be considered a Fennoscandian specialty, which had its heyday in Sweden and Finland after World War II (Parviainen 1996, Niklasson and Granström 2004). At that time, burnings were an essential method when these countries decided to rapidly transform their forests into even-aged, cultivated stands and to practice modern, intensified forestry. In Russian Karelia, similar prescribed burnings were common in the 1920s and 1930s, but after that, they gradually diminished and were finally forbidden in 1993 (Shorohova et al. 2019).

In Finland, the annual area burned in prescribed burnings during the 1950s and early 1960s varied between 15, 000 and 35,000 ha, but after mechanical site preparation became more common and largely replaced prescribed burnings, a quick and steep decline in annual prescribed burning areas took place, which led to a decrease to approximately one tenth of the previous annual prescribed burning area levels (Fig. 3, see also Parviainen 1996). Lately, silvicultural burnings have been modified to also safeguard biodiversity through leaving and burning retention trees to create fire-affected wood and habitat for firedependent species, following the recommendations from ecological research. According to research evidence, the amount of retention should be clearly higher than the current Finnish practice of leaving less than $2 \%$ of the stand volume as living retention trees in clear-cut areas of private forests (Kuuluvainen et al. 2019). Retention levels of $10-20 \%$ of stand volume (Heikkala et al. 2014, Heikkala 2016) have been recommended with minimum levels of at least $10 \mathrm{~m}^{3} /$ ha (Hyvärinen et al. 2006, Heikkala 2016).

Because of the increasing emphasis on nature management for biodiversity, these burnings with retention (Fig. 4a) are often termed as nature-management prescribed burnings or "prescribed burning to promote the biodiversity of forests," as defined in the Temporary Act on the Financing of Sustainable Forestry (2015). This act gives an opportunity to receive a $100 \%$ subsidy for the burning and also compensation of the value of the burned retention trees.

In recent years, the new practice of burning of single retention-tree groups (Fig. 4b) has been introduced in Finland (Lindberg et al. 2018). The aim of this type of burning is purely to maintain biodiversity with the idea of creating small (typically $0.1-0.2$ ha) fire-affected habitat patches. The amount of retention in these patches is usually low with just a few individual trees (total volume typically $2-5 \mathrm{~m}^{3}$ and occasionally exceeding $10 \mathrm{~m}^{3}$ ). Retention-tree-group burning is based on the idea that the ability of pyrophilous insects to detect smoke and fire even from long distances (Wikars 1997) enables them to colonize even small burned patches. This kind of retention-tree burning was introduced in the late 2000s, and it quickly gained support in public discourse although the popularity in terms of number of burnings realized remained lower than expected. The main cause and advantage of the promotion of retention-tree-group burnings were mainly practical. Such burnings are significantly less laborious, cheaper, less risky, and less demanding to perform than traditional burnings of larger areas. In particular, the often time-consuming and tedious post-burning watch can be avoided. In recent years, retention-tree-group burnings have been actively promoted with the aim of replacing the traditional silvicultural burnings. The main indication of this trend was the recent modification of the prescribed burning criterion of the Finnish PEFC forest-certification standard, 


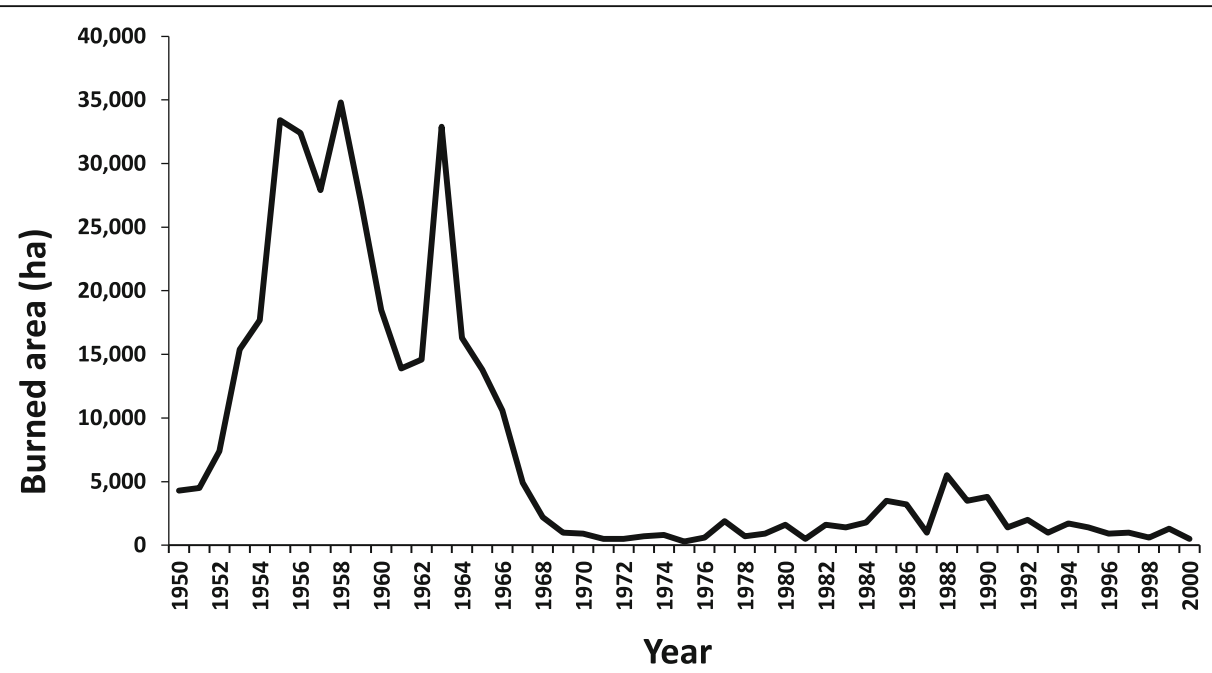

Fig. 3 Annual areas (hectares) of prescribed burnings in Finland in 1950-2000 (source: Finnish Forest Statistics 2019)

which covers $>90 \%$ of managed forests in Finland. In the recently revised 2014 standard (PEFC Finland 2014), the former area-based criterion was changed to a countbased criterion, which made it possible to fulfill the requirements of the criterion with relatively few retentiontree-group burnings.
Despite their broad support among practical agents, retention-tree-group burnings have also received criticism: (1) the effects of the method have hardly been studied at all, so scientific evidence of its possible ecological efficiency is largely lacking, and (2) the idea and aim of the method is intended to benefit pyrophilous insects, yet

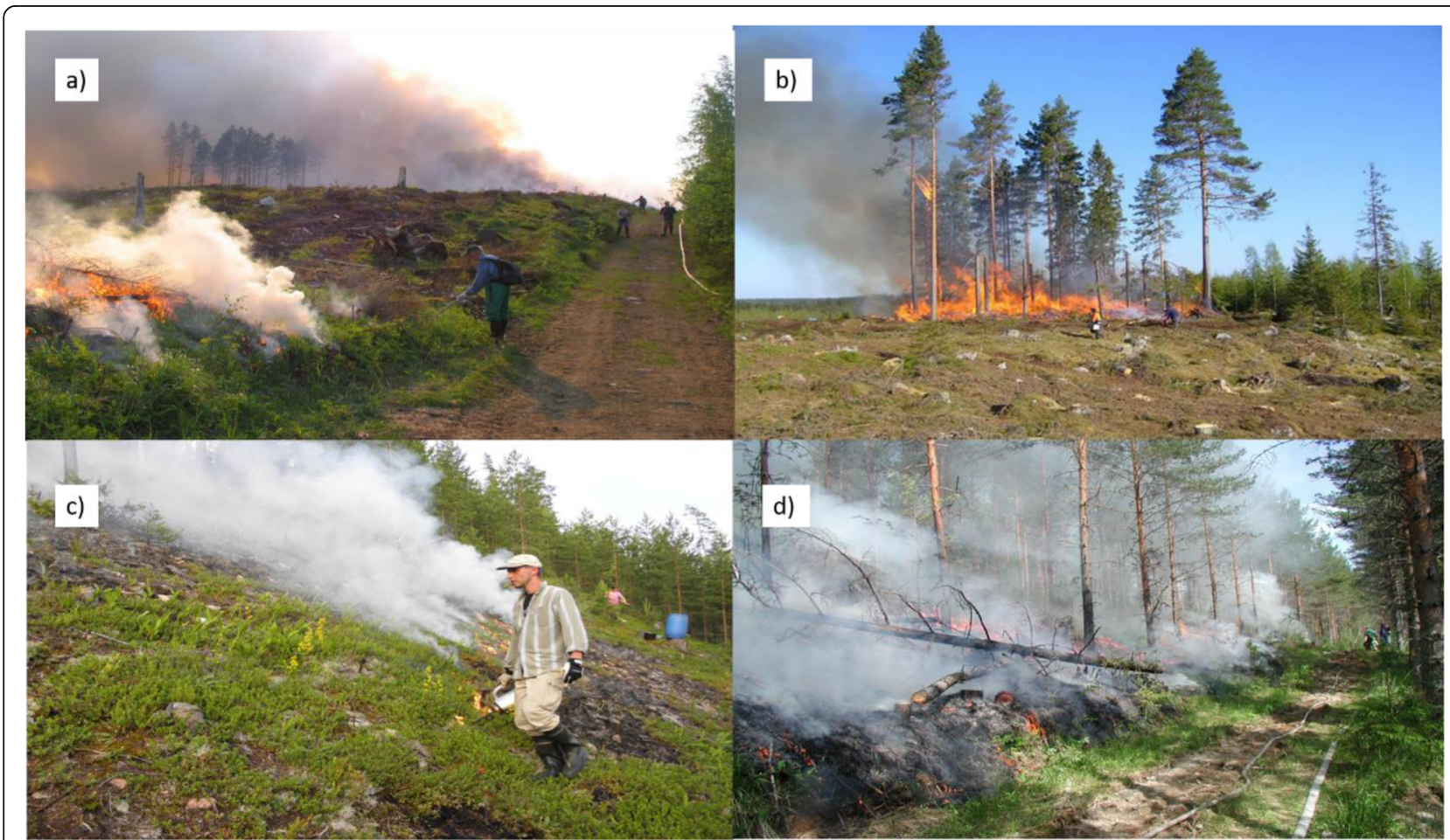

Fig. 4 Examples of different types of prescribed burning in Finland: a silvicultural prescribed burning with retention, $\mathbf{b}$ burning of a single retention-tree group, $\mathbf{c}$ habitat management burning of a sun-exposed esker slope, $\mathbf{d}$ restoration burning of a managed Scots pine stand in a conservation area. Photos: Henrik Lindberg (a), Juha-Matti Valonen (b), Timo Vesanto (c), Raimo Ikonen (d) 
there are many more species groups with poorer colonizing ability utilizing fire-driven habitats that probably benefit less from the reduced size of the burned patches. Further, (3) the amount of the main resource that retention-tree-group burning aims to produce, fireaffected or charred wood, is very low compared to traditional burnings where the large volume of burned stumps provides an important resource benefitting saproxylic species like polypores (Suominen et al. 2018). The pooled volume of cut stumps in regeneration areas typically varies between 50 and $150 \mathrm{~m}^{3} /$ ha depending on the tree species and standing stock (e.g., Lindblad et al. 2013), so a single 10-ha traditional burning with 10 retention-tree groups each may easily produce $500-1500 \mathrm{~m}^{3}$ of charred, coarse stump wood in addition to the $10-50 \mathrm{~m}^{3}$ of retention trees, whereas using the new small retention-tree-group burning alternative should yield only maybe $2-10 \mathrm{~m}^{3}$ of burned retention trees in the same area. Finally, (4) the retention-tree-group burning practice produces a relatively low number of small burned patches quite similaror even smaller-to those created by forest fires in Finland today, so the ecological added value of the practice can be questioned.

Burnings are recommended as natural and effective treatments to restore and enhance the biodiversity of sun-exposed and barren habitats such as xeric forests and esker slopes (Tukia et al. 2015). The main goals of these burnings are to reduce biomass, make moss and raw humus layers thinner, reveal mineral soil, and, in general, shape the biotope in a more extreme and barren direction, which affects the competition circumstances and benefits species that thrive in these habitats. Such burnings are therefore termed impoverishment burnings or management burnings of sun-exposed and xeric habitats (Fig. 4c). These burnings are often targeted in areas with groundwater reserves, so there is a risk that groundwater could become contaminated which, may limit the use of burnings (Similä and Junninen 2012).

Restoration burnings (Fig. 4d) are performed in conservation areas with the aims of starting natural succession after fire, diversifying stand structure and tree-species composition, improving the continuity of decaying wood, and promoting suitable resources and habitats for fire-dependent species (Similä and Junninen 2012). Within the network of protected areas in Finland, restoration burnings are typically targeted at stands that previously were managed, young or middle-aged, pine-dominated, and near-monocultural stands. A common practice is to thin the stands prior to burning with the aim of reducing fire intensity, thus easing the burning event (see the Finnish guidelines in Similä and Junninen 2012). These burnings can therefore also be considered as burning with retention practice.

The Finnish guidelines for silvicultural prescribed burnings (Lemberg and Puttonen 2002) and restoration burnings (Similä and Junninen 2012) partially differ from the Swedish practice. In Sweden, one central goal in addition to benefitting fire-dependent species is to restore and maintain the formerly common pinedominated multi-storied forests, which have gradually declined in the area and developed into more dense, mesic, and spruce-dominated direction (Granström 2001, Rydkvist 2008). Yet in Sweden also, burnings of clear-cuts are still common, especially on the lands of forest companies. During the years 2011-2015, the average annual area of prescribed burnings was a little over 1200 ha, of which more than a half were burnings of clear-cuts (Ramberg et al. 2018).

\section{The recent development of prescribed burnings in Finland}

Despite the growing awareness of the need to increase the area of prescribed burnings, there has been a clear further declining trend in prescribed burnings in the 2000 s with the current annual area being less than 500 ha (Fig. 5). The restoration burnings in protected areas cover an annual area of approximately 100 ha (Fig. 5). Overall, it can be estimated that the average pooled area of annual wildfires, restoration burnings, and prescribed burnings in recent years has been a little less than 1000 ha with more than one half being wildfires and less than one half being different types of prescribed burnings. This is about $0.004 \%$ of Finland's 26 million hectares of forestry land (Finnish Forest Statistics 2019).

The Finnish Forest Statistics (2019) do provide neither the surface area nor the number of retention-tree-group burnings, and they cannot be traced even from the original data sets behind these statistics (Aarre Peltola, Natural Resources Institute Finland, pers. comm.). Such data are not provided by the auditing practice of the Finnish PEFC forest certification system (Heli MutkalaKähkönen, The Central Union of Agricultural Producers and Forest Owners, pers. comm.), so we contacted central forest operators that perform or finance retention-treegroup-burnings. Based on these inquiries to Metsähallitus Forestry Ltd (Arto Kammonen, pers. comm., Ann-Mari Kuparinen, pers. comm., Timo Nyman, pers. comm.), Finsilva Plc (Janne Soimasuo, pers. comm.), Tornator Plc (Heikki Myöhänen, pers. comm.), UPM Wood Sourcing and Forestry (Juha-Matti Valonen, pers. comm.), and the Finnish Forest Centre (Jarmo Uimonen, pers. comm.), it can be estimated that, in recent years (2016-2018), the annual number of retention-tree-group burnings has most likely been between 30 and 50, with a total annual area of 5-10 ha, which can be considered negligible.

\section{Conclusions and recommendations}

The absence of fire has led to a severe decline in firedependent habitat types and many forest species in 


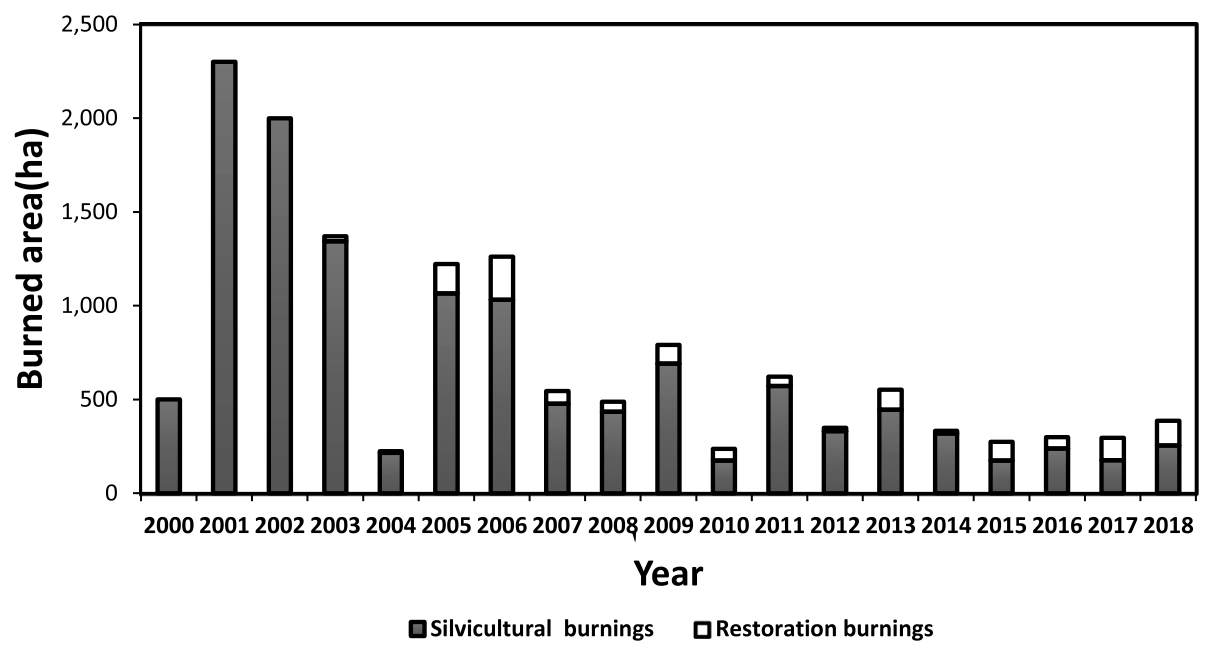

Fig. 5 Annual areas (hectares) of prescribed burnings (silvicultural and restoration burnings presented separately) in Finland 2000-2018 (sources: silvicultural burnings: Finnish Forest Statistics 2019; restoration burnings: Rauli Perkiö, Metsähallitus Parks \& Wildlife Finland, pers. comm.)

Finland (see above). With the current fire regime, there is an urgent need to increase prescribed burnings combined with sufficient retention. If the decline of firedependent species and habitat types continues and the demands set by, for example, the European Union Habitats Directive (Council Directive 1992) are to be fulfilled, an increase in prescribed burnings is essential.

The biodiversity benefits of prescribed burnings with large amounts of retention trees have been shown to be superior compared to burnings with lesser retention, let alone compared to ordinary clear-cuttings without burning (see above). Such burnings with sufficient retention have been shown to be especially beneficial for threatened saproxylics: when the amount of largediameter retention trees increases, also the number of saproxylic species increases (e.g., Toivanen and Kotiaho 2007b, see also Penttilä et al. 2013).

Despite the abovementioned concerns, there has been a further decreasing trend in burnings, which can be explained by several simultaneous recent changes in Finnish forest policies and guidelines:

1. The Temporary Act on the Financing of Sustainable Forestry (2015) gives the opportunity to subsidize prescribed burnings by private forest owners with $100 \%$ support, aiming to improve subsidizing practice compared to the previous corresponding act (Act on the Financing of Sustainable Forestry 1996), where a 50\% compensation based on average costs was available. Yet, the cuts in subsidy budgets and the prioritization policy of the Finnish Forest Centre practically ended the public subsidization of burnings in 2016. Recently, this funding has been re-evaluated and support for private land-owners is available again, yet the current subsidizing system is relatively impractical and does not adequately encourage landowners to perform burnings.

2. The criterion concerning prescribed burning (and the use of fire generally to aid biodiversity) has been gradually weakened in the standard of Finnish PEFC forest certification, which covers 92\% of managed forests in Finland. The original ambitious target to "double the area burned" during the first 5-year period of the certification (Suomen metsäsertifiointijärjestelmä 1998) was halved as early as in the first update of the PEFC standard by setting the target of "keeping the area burned at the same level." The updated standard also accepted all wildfires, burnings of small retention-tree groups, and even restoration burnings in conservation areas as substitutes for the prescribed burnings of regeneration areas (Metsäsertifioinnin standardityöryhmä 2003). In the second update of the PEFC standard, ecological impairments were continued further by making it possible to substitute surface area (hectares) burned with counts of sites burned disregarding their surface area (PEFC Finland 2009). Finally, in the latest update of the PEFC standard, only the numbers of burnings regardless their surface areas were counted (PEFC Finland 2014). In the current version of the standard (PEFC Finland 2014), the criterion stipulates only one burning per year per 200,000 ha, and also burnings of retention-tree groups, wildfires $>5$ ha, and restoration burnings in protected areas can be counted in. The traditional large burnings with variable amounts of retention trees were therefore replaced partly with the new practice of burning retentiontree groups and partly with wildfires. 
3. The State-owned forestry company Metsähallitus Forestry Ltd categorically abandoned prescribed burnings in 2016, which led to a significant decrease in burnings, since Metsähallitus Forestry Ltd had performed roughly half of the burnings in the preceding years in Finland, although state forests cover only $17 \%$ of the forestry land available for wood production (Peltola 2014).

The only major positive action connected to prescribed burnings has been the establishment of FSC certification in Finland (mainly in the forests of large forest companies) although, in this standard too, there has been impairment from its very first version (The Board of the Finnish FSC Association 2005), when the requirement was to use prescribed burning on at least $5 \%$ of the appropriate regeneration cut areas over a 5 -year period. The current criterion (6.2.8) of the FSC standard concerning prescribed burning, however, still states that "The forest owner $(>10,000 \mathrm{ha})$ shall use prescribed burning to maintain habitats of species dependent on forest fires. The minimum total area of prescribed burnings performed annually shall be $3 \%$ of the regeneration felling area of suitable sites (MT and poorer sites) over a 5 -year period. The purpose is to produce a minimum average of 20 fire-damaged stems $(\mathrm{DBH}>20$ $\mathrm{cm}$ in Southern Finland, DBH $>10 \mathrm{~cm}$ in Northern Finland) per hectare in the burnt area" (Finnish FSC Association 2010). According to the same criterion: "If stands $(>0.2 \mathrm{ha}$ ) with all their trees are burnt, their area can be calculated in the area target five-fold." FSC-certified forests currently cover approximately 1.8 million hectares $(10 \%)$ of Finland's forest land under commercial use (FSC Suomi 2018), and as annual burnings in FSC-certified forests in recent years in this area have covered 150-250 ha (Heikki Myöhänen, Tornator Plc, pers. comm., Janne Soimasuo, Finsilva Plc, pers. comm., Juha-Matti Valonen, UPM Wood Sourcing and Forestry, pers. comm.), their contribution to the total area burned in Finland is notable.

Despite the generally accepted goal of increasing the volume of restoration burnings in conservation areas, their annual amount has remained at the same low level, and with current funding, their increase is improbable (Rauli Perkiö, Metsähallitus Parks \& Wildlife Finland, pers. comm.).

The main reasons behind the general decreasing trend of burnings are the following: burnings are laborious, expensive, weather-sensitive, and entail risks of, for example, fire escape (Lindberg and Vanha-Majamaa 2004). Unfortunately, none of these problems has been solved. The costs of burnings have increased in the last 20 years from less than $€ 500 /$ hectare to the current $€ 2000-2500$ / hectare (Lindberg et al. 2018). Also, the decreasing size of regeneration areas and steeply increased harvesting of logging residues for bioenergy have reduced the amount of potential burning areas. It is also probable that general attitudes in society have grown more cautious towards the use of fire in forests. This increases responsibility and pressure on the persons performing the burnings. Despite the clear benefits shown by research evidence, it is simply easier not to burn.

The current fire regime and practices of prescribed burnings evidently cannot safeguard the future of firedependent species and fire-driven habitats in Finland. Because of this, we recommend the following actions: (1) a clear target with sufficient financing of prescribed burnings should be set. (2) The response of pyrophilous species to current burnings in Finland has been shown to be dependent on previous fire activity, i.e., fire continuity (Kouki et al. 2012), so burnings should be targeted at specific fire-continuum areas to ensure the continuity of fire-affected habitats at landscape level. These areas were already introduced by the working group on restoration appointed by the Ministry of the Environment (Ennallistamistyöryhmä 2003) and by Metsähallitus Parks \& Wildlife Finland (Hyvärinen 2008). The areas should be re-evaluated and should include all landowners, not only the state forests. A database monitoring all fire events in forests should be developed to help the planning and targeting of burnings as suggested in Sweden by Ramberg et al. (2018). (3) The current subsidizing policies should be renewed to encourage private landowners to perform prescribed burnings. (4) The ecological impact of the current prescribed burning criterion of the Finnish PEFC forestcertification standard is negligible, so it should be modified to become more effective. (5) The practice of retention-tree-group burning is currently lacking ecological credibility because of the tiny areas and small numbers that they cover and because of their general sporadic nature. They appear to be performed mainly in order to fulfill the requirements of the PEFC certification criterion of prescribed burnings, not to safeguard firedependent species and habitats. State subsidizing should therefore be targeted at larger areas. If there is a desire for retention-group-burnings to have a true ecological impact, they should be developed on the basis of sound ecological reasoning. The functionality of the method should be studied and compilation of statistics about the burnings should be developed in order to gain estimates of the general impact of the practice. (6) Political steering should be used to re-introduce prescribed burnings in commercial state forests. (7) The financial resources allocated to burnings performed in conservation areas should be increased. (8) Landowners should be encouraged to form conservation areas in wildfire areas, especially larger ones. The establishment of such conservation areas is currently made possible by the Forest Biodiversity Programme for Southern Finland (METSO) (see Syriänen et al. 2016), yet the problem has been the fact that 
compensation for burned timber has not been able to compete with the purchase price offered by timber companies, so these compensation policies should be re-evaluated.

\section{Abbreviations}

FSC: Forest Stewardship Council; PEFC: Programme for the Endorsement of Forest Certification; VRF: Variable retention forestry

\section{Acknowledgements}

We thank all persons named in text who have provided us information and photographs and an anonymous reviewer for commenting the manuscript.

\section{Authors' contributions}

HL presented the first version and compiled the final version of the manuscript based on writing and comments by PP and IVM. All authors read and approved the final manuscript.

\section{Funding}

The authors did not receive any funding directed to preparation of this manuscript.

\section{Availability of data and materials}

Since this is a review article, no original data were used.

\section{Ethics approval and consent to participate}

Not applicable

\section{Consent for publication}

Not applicable

\section{Competing interests}

The authors declare that they have no competing interests.

\section{Author details}

${ }^{1}$ Häme University of Applied Sciences, Visamäentie 35 A Box 230, Fl-13101 Hämeenlinna, Finland. ${ }^{2}$ Finnish Environment Institute, Latokartanonkaari 11, Fl-00790 Helsinki, Finland. ${ }^{3}$ Natural Resources Institute Finland (Luke), Latokartanonkaari 9. Fl-00790 Helsinki, Finland.

Received: 27 September 2019 Accepted: 6 December 2019

\section{Published online: 15 January 2020}

\section{References}

Aarne M (ed) (1992) Metsätilastollinen vuosikirja 1990-91 (Yearbook of forest statistics 1990-91). SVT Maa- ja metsätalous (SVT Agriculture and forestry) 1992(3):1-281. Folia Forestalia 790:1-281

Act on the Financing of Sustainable Forestry (1996) Laki kestävän metsätalouden rahoituksesta 12.12.1996/1094 (In Finnish. https://finlex.fi/fi/laki/ajantasa/ kumotut/1996/19961094. Accessed 10 September, 2019.

Äijälä O, Koistinen A, Sved J, Vanhatalo K, Väisänen P (eds) (2019) Metsänhoidon suositukset. [Forest management guidelines. In Finnish]. Tapion julkaisuja. 252 p.

Angelstam PK (1998) Maintaining and restoring biodiversity in European boreal forests by developing natural disturbance regimes. J Veg Sci 9:593-602

Armstrong GW (1999) A stochastic characterisation of the natural disturbance regime of the boreal mixedwood forest with implications for sustainable forest management. Can J Forest Res 29:424-433

Bergeron Y, Harvey B, Leduc A, Gauthier S (1999) Forest management guidelines based on natural disturbance dynamics: stand- and forest-level considerations. Forest Chron 75:49-54

Bergeron Y, Leduc A, Harvey BD, Gauthier S (2002) Natural fire regime: a guide for sustainable management of the Canadian boreal forest. Silva Fennica 36:81-95

Berglund H, Jönsson MT, Penttilä R, Vanha-Majamaa I (2011) The effects of burning and dead-wood creation on the diversity of pioneer woodinhabiting fungi in managed boreal spruce forests. Forest Ecol Manag 261:1293-1305

Betänkande av 2018 års skogsbrandsutredning (2019) Skogsbränderna sommaren 2018 [Forest fires in summer 2018, in Swedish]. Statens offentliga utredningar (SOU) 2019:7, Stockholm. 334 p.
Council Directive (1992) Council Directive 92/43/EEC of 21 May 1992 on the conservation of natural habitats and of wild fauna and flora. Official J Eur Communities No L 206:7-50

Eales J, Haddaway NR, Bernes C, Cooke SJ, Jonsson BG, Kouki J, Petrokofsky G, Taylor JJ (2018) What is the effect of prescribed burning in temperate and boreal forest on biodiversity, beyond pyrophilous and saproxylic species? A systematic review. Environ Evid 7:19

Ennallistamistyöryhmä (2003) Ennallistaminen suojelualueilla. Ennallistamistyöryhmän mietintö [In Finnish with an English summary: Restoration in protected areas: report by the working group on restoration]. Suomen ympäristö [The Finnish Environment] 618:1-220

Esseen P-A, Ehnström B, Ericson L, Sjöberg K (1997) Boreal forests. Ecol Bull 46:16-47

Fernandes PM, Davies GM, Ascoli D, Fernández C, Moreira F, Rigolot E, Stoof CR, Vega JA, Molina D (2013) Prescribed burning in southern Europe: developing fire management in a dynamic landscape. Front Ecol Environ 11(Suppl. 1): e4-e14

Finnish Forest Statistics (2019) Silvicultural and forest improvement work: prescribed burning. http://statdb.luke.fi/PXWeb/pxweb/en/LUKE/. Accessed 22 August, 2019

Finnish FSC Association (2010) FSC Standard for Finland. Finnish FSC Association, https://fi.fsc.org/download.fsc-standard-for-finland-v1-1-approved-210111.a-2 02.pdf. Accessed 9 September, 2019. $45+21$ p.

Franklin JF, Berg DF, Thornburg D, Tappeiner JC (1997) Alternative silvicultural approaches to timber harvesting: variable retention harvest systems. In Kohm KA, Franklin JF (eds) Creating a forestry for the 21st century: the science of ecosystem management. Island Press, Washington, D.C., pp 111-139

From S (ed) (2005) Paahdeympäristöjen ekologia ja uhanalaiset lajit [In Finnish with an English summary: the ecology and threatened species of sunny and dry habitats]. Suomen ympäristö [The Finnish Environment] 774. 86 p.

FSC Suomi (2018) Toimintakertomus 2018 [Annual report 2018. In Finnish]. FSC Suomi. $15 \mathrm{p}$

Gauthier S, Vaillancourt M-A, Leduc A, De Grandpré L, Kneeshaw D, Morin H, Drapeau P, Bergeron Y (2009) Ecosystem management in the boreal forest. Natural Resources Canada. Canadian Forest Service, Laurentian Forestry Centre, Quebec, Quebec, p 492

Granström A (2001) Fire management for biodiversity in the European boreal forest. Scand J Forest Res:62-69

Gustafsson L, Berglind M, Granström A, Grelle A, Isacsson G, Kjellander P, Larsson S, Lindh M, Pettersson LB, Strengbom J, Stridh B, Sävström T, Thor G, Wikars L-O, Mikusiński G (2019) Rapid ecological response and intensified knowledge accumulation following a north European mega-fire. Scand J Forest Res 34:234-253

Gustafsson L, Hannerz M, Koivula M, Shorohova E, Vanha-Majamaa I, Weslien J (2020) Research on retention forestry in Northern Europe. Ecol Process https://doi.org/10.1186/s13717-019-0208-2

Haataja V (1998) Tuntsan palo ja suuri nokisavotta. [Tuntsa wildfire. In Finnish]. Koillismaan Kirjapaino Oy, Kuusamo. 48 p.

Haikerwal A, Reisen F, Sim MR, Abramson MJ, Meyer CP, Johnston FH, Dennekamp M (2015) Impact of smoke from prescribed burning: is it a public health concern? J Air Waste Manag Assoc 65:592-598

Heikkala O (2016) Emulation of natural disturbances and the maintenance of biodiversity in managed boreal forests: the effects of prescribed fire and retention forestry on insect assemblages. Dissertationes Forestales 222:1-46

Heikkala O, Martikainen P, Kouki I (2017) Prescribed burning is an effective and quick method to conserve rare pyrophilous forest-dwelling flat bugs. Insect Conserv Diver 10:32-41

Heikkala O, Seibold S, Koivula M, Martikainen P, Müller J, Thorn S, Kouki J (2016) Retention forestry and prescribed burning result in functionally different saproxylic beetle assemblages than clear-cutting. Forest Ecol Manag 359:51-58

Heikkala O, Suominen M, Junninen K, Hämäläinen A, Kouki J (2014) Effects of retention level and fire on retention tree dynamics in boreal forests. Forest Ecol Manag 328:193-201

Hunter ML (1993) Natural fire regimes as spatial models for managing boreal forests. Biol Conserv 65:115-120

Hyvärinen E (2008) Fire as a management tool in protected areas: principles and practices in Finland. In: Hovi M, Kytö H, Rautio S-K (eds), Fire and forest - the international forest fire symposium in Kajaani 13-14.11.2007. Metsähallituksen luonnonsuojelujulkaisuja. Sarja A [Nature Protection Publications of Metsähallitus. Series A] 175. pp 21-22 
Hyvärinen E, Juslén A, Kemppainen E, Uddström A, Liukko U-M (eds) (2019) Suomen lajien uhanalaisuus - Punainen kirja 2019/The 2019 Red List of Finnish Species. Ympäristöministeriö \& Suomen ympäristökeskus/Ministry of the Environment \& Finnish Environment Institute, Helsinki. 703 p.

Hyvärinen E, Kouki J, Martikainen P (2006) Fire and green-tree retention in conservation of red-listed and rare deadwood-dependent beetles in Finnish boreal forests. Conserv Biol 20:1711-1719

Hyvärinen E, Kouki J, Martikainen P (2009) Prescribed fires and retention trees help to conserve beetle diversity in managed boreal forests despite their transient negative effects on some beetle groups. Insect Conserv Diver 2:93-105

Hyvärinen E, Kouki J, Martikainen P, Lappalainen H (2005) Short-term effects of controlled burning and green-tree retention on beetle (Coleoptera) assemblages in managed boreal forests. Forest Ecol Manag 212:315-332

Johnson EA (1992) Fire and vegetation dynamics: studies from the North American boreal forest. Cambridge University Press, New York, 129 p.

Koivula M, Vanha-Majamaa I (2020) Experimental evidence on biodiversity impacts of variable retention forestry, prescribed burning and deadwood manipulation in Fennoscandia Ecol Process (in press).

Kontula T, Raunio A (eds) (2018) Suomen luontotyyppien uhanalaisuus 2018. Luontotyyppien punainen kirja. Osa 1 - tulokset ja arvioinnin perusteet. [In Finnish with an English summary: Threatened habitat types in Finland 2018 Red List of habitats. Part I: Results and basis for assessment.]. Suomen ympäristö [The Finnish Environment] 5/2018. 388 p.

Kotiaho JS, Kuusela S, Nieminen E, Päivinen J (eds) (2015) Elinympäristöjen tilan edistäminen Suomessa. ELITE-työryhmän mietintö elinympäristöjen tilan edistämisen priorisointisuunnitelmaksi ja arvio suunnitelman kokonaiskustannuksista. [In Finnish with an English summary: Improving the status of habitats in Finland - report of the ELITE working group on a prioritisation plan for improving the status of habitats and estimated total costs of the plan.]. Suomen ympäristö [The Finnish Environment] 8/2015. 246 p.

Kouki J (2019) Fire and retention trees in facilitating biodiversity in boreal forests. http://forest.ueffi//jarikouki/project_fire.htm. Accessed 24 August, 2019.

Kouki J, Hyvärinen E, Lappalainen H, Martikainen P, Similä M (2012) Landscape context affects the success of habitat restoration: large-scale colonization patterns of saproxylic and fire-associated species in boreal forests. Divers Distrib 18:348-355

Kuuluvainen T (2009) Forest management and biodiversity conservation based on natural ecosystem dynamics in Northern Europe: The complexity challenge. Ambio 38:309-315

Kuuluvainen T (2016) Ecosystem management of the boreal forest. Oxford Research Encyclopedia of Environmental Science DOI: https://doi.org/10. 1093/acrefore/9780199389414.013.15.

Kuuluvainen T, Aakala T (2011) Natural forest dynamics in boreal Fennoscandia: a review and classification. Silva Fennica 45:823-841

Kuuluvainen T, Lindberg H, Vanha-Majamaa I, Keto-Tokoi P, Punttila P (2019) Lowlevel retention forestry, certification and biodiversity: case Finland. Ecol Process 8:47. https://doi.org/10.1186/s13717-019-0198-0

Lampainen J, Kuuluvainen T, Wallenius TH, Karjalainen L, Vanha-Majamaa I (2004) Long-term forest structure and regeneration after wildfire in Russian Karelia. J Veg Sci 15:245-256

Lehmusluoto P (1956) Kulot, kulontorjunta ja metsäpalovakuutus [Forest fires, forest fire protection, and forest fire insurance. In Finnish]. In: Jalava $M$, Lihtonen V, Heiskanen V, Sippola H (eds), Metsäkäsikirja 1 [Forest Handbook 1. In Finnish]. Kustannusosakeyhtiö Kivi, Helsinki, pp 717-742

Lemberg T, Puttonen P (2002) Kulottajan käsikirja [Guide for prescribed burning. In Finnish]. Metsälehti kustannus. 113 p.

Lilja S, De Chantal M, Kuuluvainen T, Vanha-Majamaa I, Puttonen P (2005) Restoring natural characteristics in managed Norway spruce Picea abies (L.) Karst. stands with partial cutting, dead wood creation and fire: immediate treatment effects. Scand J Forest Res 20(Suppl. 6):68-78

Lindberg H, Saaristo L, Nieminen A (2018) Tuli takaisin metsiin [Bring fire back to forests. In Finnish]. Tapion raportteja 30:1-30

Lindberg H, Vanha-Majamaa I (2004) Promoting fire in Finnish forests during last decade - theory and practice. Transactions of the Faculty of Forestry, Estonian Agric University 37:86-91

Lindblad J, Jahkonen M, Laitila J, Kilpeläinen H, Sirkiä S (2013) Energiapuun määrä ja laatu sekä niiden arviointi [The volume, quality and estimation of energy wood. In Finnish]. Metlan työraportteja [Working Papers of the Finnish Forest Research Institute] 259: 1-53.

Lynham TJ, Wickware GM, Mason JA (1998) Soil chemical changes and plant succession following experimental burning in immature jack pine. Can J Soil Sci 78:93-104
Metsäsertifioinnin standardityöryhmä (2003) FFCS 1002-1:2003, Ryhmäsertifioinnin kriteerit metsäkeskuksen toimialueen tasolla [Finnish forest certification standard FFCS 1002-1:2003. In Finnish]. Metsäsertifioinnin standardityöryhmä 29.9.2003. $17 \mathrm{p}$

Neary DG, Landsberg JD, Tiedemann AR, Ffolliott PF (2005) Water quality. In: Neary DG, Ryan KC, DeBano LF (eds), Wildland fire in ecosystems: effects of fire on soil and water. USDA Forest Service General Technical Report RMRS GTR-42, vol. 4. pp 119-134

Niklasson M, Granström A (2004) Fire in Sweden - history, research, prescribed burning and forest certification. Int Forest Fire News 30 (January-June 2004): $80-83$

Olsson J, Jonsson BG (2010) Restoration fire and wood-inhabiting fungi in a Swedish Pinus sylvestris forest. Forest Ecol Manag 259:1971-1980

Parviainen J (1996) Impact of fire on Finnish forests in the past and today. Silva Fennica 30:353-359

PEFC Finland (2009) PEFC Finland Standard. Criteria for group certification. Level of a forestry centre or a forest management association. PEFC FI 1002:2009. 34 p.

PEFC Finland (2014) PEFC Finland Standard. Criteria for PEFC Forest Certification. PEFC FI 1002:2014. 49 p.

Peltola A (ed) (2014) Metsätilastollinen vuosikirja 2014 (Finnish Statistical Yearbook of Forestry). SVT Maa-, metsä- ja kalatalous 2014 (Official Statistics of Finland: Agriculture, forestry and fishery). Metsäntutkimuslaitos (Finnish Forest Research Institute). $428 \mathrm{p}$

Penttilä R, Junninen K, Punttila P, Siitonen J (2013) Effects of forest restoration by fire on polypores depend strongly on time since disturbance - a case study from Finland based on a 23-year monitoring period. Forest Ecol Manag 310: 508-516

Penttilä R, Kotiranta H (1996) Short-term effects of prescribed burning on woodrotting fungi. Silva Fennica 30:399-419

Programme of Prime Minister Sanna Marin's Government (2019) Inclusive and competent Finland - a socially, economically and ecologically sustainable society. Publications of the Finnish Government 2019:33. 228 p

Ramberg E, Strengbom J, Granath G (2018) Coordination through databases can improve prescribed burning as a conservation tool to promote forest biodiversity. Ambio 47:298-306

Rassi P, Hyvärinen E, Juslén A, Mannerkoski I (eds) (2010) Suomen lajien uhanalaisuus - Punainen kirja 2010. The 2010 Red List of Finnish Species. Ympäristöministeriö ja Suomen ympäristökeskus, Ministry of the Environment and Finnish Environment Institute, Helsinki. 685 p.

Raunio A, Schulman A, Kontula T (eds) (2008) Suomen luontotyyppien uhanalaisuus - Osa 1: Tulokset ja arvioinnin perusteet [In Finnish with an English summary: Assessment of threatened habitat types in Finland - Part 1: Results and basis for assessment]. Suomen ympäristö [The Finnish Environment] 8/2008. 264 p.

Robinne F-N, Burns J, Kant P, de Groot B, Flannigan MD, Kleine M, Wotton DM (eds) (2018) Global fire challenges in a warming world. Summary note of a global expert workshop on fire and climate change. International Union of Forest Research Organizations, IUFRO Occasional Paper No. 32. 58 p.

Rodríguez A, Kouki J (2015) Emulating natural disturbance in forest management enhances pollination services for dominant Vaccinium shrubs in boreal pinedominated forests. Forest Ecol Manag 350:1-12

Ryan KC, Knapp EE, Varner JM (2013) Prescribed fire in North American forests and woodlands: history, current practice, and challenges. Front Ecol Environ 11(Suppl. 1):E15-E24

Rydkvist T (2008) Principles and practices in Sweden. In: Hovi M, Kytö H, Rautio SK (eds), Fire and Forest - The International Forest Fire Symposium in Kajaani 13-14.11.2007. Metsähallituksen luonnonsuojelujulkaisuja. Sarja A [Nature Protection Publications of Metsähallitus. Series A] 175. pp 23-26

Saari E (1923) Kuloista, etupäässä Suomen valtionmetsiä silmällä pitäen. Tilastollinen tutkimus. [In Finnish with an English summary: Forest fires in Finland, with special reference to State forests. Statistical investigation.]. Acta For Fenn 26(4):1-155

Salo K (2019) The structure of macrofungal assemblages in boreal forests, with particular reference to the effect of fire on Basidiomycota and Ascomycota. Dissertationes Forestales 279:1-33

Shorohova E, Sinkevich S, Kryshen A, Vanha-Majamaa I (2019) Variable retention forestry in European boreal forests in Russia. Ecol Process 8:34. https://doi. org/10.1186/s13717-019-0183-7

Similä M, Junninen K (eds) (2012) Ecological restoration and management in boreal forests - best practices from Finland. Metsähallitus Natural Heritage Services, Vantaa, $50 \mathrm{p}$ 
Stephens SL, Burrows N, Buyantuyev A, Gray RW, Keane RE, Kubian R, Liu S, Seijo F, Shu L, Tolhurst KG, van Wagtendonk JW (2014) Temperate and boreal forest mega-fires: characteristics and challenges. Front Ecol Environ 12:115-122

Suomen metsäsertifiointijärjestelmä (1998) Standardiluonnos SMS 1002-1. SMS 1002-1 - Metsäsertifioinnin kriteeristö [Finnish forest certification standard SMS 1002-1. In Finnish]. In: Metsäsertifioinnin valmiusprojekti (ed) Suomen metsäsertifiointijärjestelmän standardiluonnokset 19.11.1998. Metsäsertifioinnin valmiusprojekti. pp 17-25.

Suominen M, Junninen K, Heikkala O, Kouki J (2015) Combined effects of retention forestry and prescribed burning on polypore fungi. J Appl Ecol 52:1001-1008

Suominen M, Junninen K, Heikkala O, Kouki J (2018) Burning harvested sites enhances polypore diversity on stumps and slash. Forest Ecol Manag 414:47-53

Syränen K, Hakalisto S, Mikkola J, Musta I, Nissinen M, Savolainen R, Seppälä J, Seppälä M, Siitonen J, Valkeapää A (2016) Monimuotoisuudelle arvokkaiden metsäympäristöjen tunnistaminen. METSO-ohjelman luonnontieteelliset valintaperusteet 2016-2025 [In Finnish with an English summary: Identification of forest ecosystems valuable in terms of biodiversity. Scientific selection criteria of the Forest Biodiversity Programme for Southern Finland (METSO) 2016-2025]. Ympäristöministeriön raportteja [Reports of the Ministry of the Environment] 17/2016: 1-75.

Temporary Act on the Financing of Sustainable Forestry (2015) Kestävän metsätalouden määräaikainen rahoituslaki 23.1.2015/34 (In Finnish). https://www.finlex.fi/fi/laki/ajantasa/2015/20150034. Accessed 10 September, 2019

The Board of the Finnish FSC Association (2005) The Draft FSC standard for Finland. Approved by the Board of the Finnish FSC Association at 17th February 2005. Finnish FSC Association. 46 p.

Toivanen T, Kotiaho JS (2007a) Burning of logged sites to protect beetles in managed boreal forests. Conserv Biol 21:1562-1572

Toivanen T, Kotiaho JS (2007b) Mimicking natural disturbances of boreal forests: the effects of controlled burning and creating dead wood on beetle diversity. Biodivers Conserv 16:3193-3211

Tukia H, Hämäläinen J, Ryttäri T (eds) (2015) Harjumetsien paahdeelinympäristöverkostot. Metsien luonnonhoidon vaikutukset harjuluontoon, maisemaan ja paahdelajiston monimuotoisuuteen. [In Finnish with an English summary: Sun-exposed esker forest habitat networks. The impact of forest management on esker habitats, landscape and the diversity of species in sun-exposed habitats.]. Suomen ympäristökeskuksen raportteja [Reports of the Finnish Environment Institute] 2/2015. 102 p.

Vanha-Majamaa I, Jalonen J (2001) Green tree retention in Fennoscandian forestry. Scand J Forest Res (Suppl. 3):79-90

Vanha-Majamaa I, Lijja S, Ryömä R, Kotiaho JS, Laaka-Lindberg S, Lindberg H, Puttonen P, Tamminen P, Toivanen T, Kuuluvainen T (2007) Rehabilitating boreal forest structure and species composition in Finland through logging, dead wood creation and fire: The EVO experiment. Forest Ecol Manag 250:77-88

Vanha-Majamaa I, Lindberg H, Heikkilä T (2004) Forest fire research in Finland. International Forest Fire News No. 30 (January-June 2004): 22-28.

Vanha-Majamaa I, Tuittila E-S, Tonteri T, Suominen R (1996) Seedling establishment after prescribed burning of a clear-cut and a partially cut mesic boreal forest in southern Finland. Silva Fennica 30:31-45

Viro PJ (1969) Prescribed burning in forestry. Comm Inst For Fenn 67(7):1-49

Viro PJ (1974) Effects of forest fire on soil. In: Kozlowski TT, Ahlgren CE (eds) Fire and ecosystems. Academic Press, New York, pp 7-45

Weber MG, McAlpine RS, Wotton BM, Donnelly JG, Hobbs MW (1995) Prescribed burning and disk trenching effects on early plantation performance in eastern Ontario, Canada. Forest Ecol Manag 78:159-171

Wikars L-O (1997) Effects of forest fire and the ecology of fire-adapted insects. Comprehensive summaries of Uppsala dissertations from the Faculty of Science and Technology 272: 1-35 + appendices.

\section{Publisher's Note}

Springer Nature remains neutral with regard to jurisdictional claims in published maps and institutional affiliations.

\section{Submit your manuscript to a SpringerOpen ${ }^{\circ}$ journal and benefit from:}

- Convenient online submission

- Rigorous peer review

- Open access: articles freely available online

- High visibility within the field

- Retaining the copyright to your article

Submit your next manuscript at $\boldsymbol{\nabla}$ springeropen.com 